\title{
Familial study revealed the association of Vitamin D receptor gene haplotype with Hansen's disease
}

\author{
NV Sanjeev ${ }^{1}$, NC Suryadevara ${ }^{1}$, Suman Jain², Vijaya Lakshmi Valluri', MPJS Anandraj ${ }^{1 *}$ \\ From First International Science Symposium on HIV and Infectious Diseases (HIV SCIENCE 2012) \\ Chennai, India. 20-22 January 2012
}

\section{Background}

Single-nucleotide polymorphism within the gene encoding Vitamin D receptor (VDR) - a member of the nuclear receptor supergene family, is associated with several infectious diseases. The receptor belongs to the family of trans-acting transcriptional regulatory factors. Studies on VDR gene polymorphism reveals Fok I, Taq I, \& Apa I restriction site variants to be significantly associated with many of the diseases compared to other SNPs within the gene. The study aims to determine the association of these polymorphisms with Hansen's disease.

\section{Methods}

The study group included six well defined multicase leprosy families with cases $(\mathrm{n}=32)$ and unaffected family members $(n=44)$. Genotyping was done for the polymorphic positions present in exon $2(\mathrm{~T} / \mathrm{C}), 9(\mathrm{~T} / \mathrm{C})$ and intron 8(C/A) regions of the VDR gene using Polymerase Chain Reaction followed by Restriction Fragment Length Polymorphism using enzymes Fok I, Taq I \& Apa I respectively. Haplotype analysis was performed for the three positions using Chi square test in SNPSTAT software.

\section{Results}

Out of all possible combinations on haplotype analysis, C-T-C $(p=0.018)$ and T-T-C $(p=0.028)$ was negatively associated with Hansen's disease and no significant association was observed with individual gene variants. The wild alleles at position Taq I and Apa I were found to be in strong linkage disequilibrium.

\footnotetext{
* Correspondence: hanandraj@yahoo.com

${ }^{1}$ LEPRA India - Blue Peter Public Health \& Research Centre, Hyderabad, AP, India

Full list of author information is available at the end of the article
}

\section{Conclusion}

The data indicates that a relationship exists between VDR polymorphic haplotype and the development of disease and the haplotypes C-T-C and T-T-C may perhaps render protection against Hansen's disease.

\section{Author details}

'LEPRA India - Blue Peter Public Health \& Research Centre, Hyderabad, AP, India. ${ }^{2}$ Thalassemia and Sickle Cell Anaemia Society (TSCS), Hyderabad, AP, India.

Published: 4 May 2012

\section{doi:10.1186/1471-2334-12-S1-P16}

Cite this article as: Sanjeev et al:: Familial study revealed the association of Vitamin D receptor gene haplotype with Hansen's disease. BMC Infectious Diseases 2012 12(Suppl 1):P16.
Submit your next manuscript to BioMed Central and take full advantage of:

- Convenient online submission

- Thorough peer review

- No space constraints or color figure charges

- Immediate publication on acceptance

- Inclusion in PubMed, CAS, Scopus and Google Scholar

- Research which is freely available for redistribution
C Biomed Central
C Biomed Central

(c) 2012 Sanjeev et al; licensee BioMed Central Ltd. This is an Open Access article distributed under the terms of the Creative Commons Attribution License (http://creativecommons.org/licenses/by/2.0), which permits unrestricted use, distribution, and reproduction in any medium, provided the original work is properly cited. 